\title{
THE COMPETITIVENESS ANALYSIS OF INDONESIA'S TOBACCO IN THE INTERNATIONAL MARKET
}

\author{
Handy Tribawana Farmanda Putra ${ }^{1 *}$, Abdul Wahib Muhaimin ${ }^{2}$, Suhartini ${ }^{2}$ \\ ${ }^{1}$ Postgraduate, Faculty of Agriculture, University of Brawijaya, Veteran Street, Malang 65145, Indonesia \\ ${ }^{2}$ Department of Socioeconomic, Faculty of Agriculture, University of Brawijaya, Veteran Street, Malang \\ 65145, Indonesia
}

Received: 13th October 2015; Revised: 5th November 2015; Accepted: 9th November 2015

\begin{abstract}
Tobacco is one of Indonesia's prosperous commodities. The export of tobacco from 2008 to 2014 was tent to increase since the harvested area for this commodity has been extended. This progress indicates that tobacco has a great chance to be developed in Indonesia. This research is aimed to measure the competitiveness of Indonesia's tobacco in the international market. Competitiveness analysis employs the Revealed Comparative Advantage (RCA), thus Export Competitiveness Index (ECI) was counted to show the competitiveness trend. The results indicate that the competitiveness of Indonesia's tobacco has a positive trend in the international market, and better progress than its competitors such as France and Thailand.
\end{abstract}

Keywords: Tobacco; RCA; revealed comparative advantage; ECI; export competitiveness index

\section{Introduction}

As a developing country, Indonesia has been actively involved in any international trading activities, both export and import. Competitiveness at international market gets Indonesia's comparative advantage become its competitive advantage and enhance its economy growth then (Firmansyah, 2014). According to Bariroh (2004), competitiveness of a commodity from a country could be seen from its efficiency on producing that commodity, compares with another producer countries based on their export and import performances.

Tobacco is one of excellence commodity of Indonesia, especially for export. According to The General Directory of Plantation (2014), national excellence commodity is a commodity that has priority in long-term development programs, which are designed to increase productivity, foreign exchange and export value; substitute imported product; and to fulfil domestic demand. In the 2014, industry of tobacco processing gives a strategic role in generating the national economy, especially for tobacco production and for cigarette industry. Increasing in number of harvested area for tobacco, since 2008, at which the average growth

\footnotetext{
*) Correspondence author

E-mail: handytribawana@yahoo.com

Phone: +62 8563106852
}

rate is 4 percent per year, indicates that this commodity has a good prospect to be developed. This condition is occurred since tobacco farming seems to be more prosperous for farmers so they start to invest on tobacco farming.

While the harvested area of tobacco has been increasing, but there is no certainty that it would bring a positive impact on production number. The data shows that production of Indonesia's tobacco from 2007 to 2012 tend to decrease. The only progress noted along that period was in 2011, at which tobacco production increased 45 thousand tons from previous year.

Besides Indonesia, there are other producer countries of tobacco such are Brazilia, India, and United State of America. Based on FAO, Indonesia's production of tobacco is the fifth biggest among them. But its export quantity is the second smallest ones. Table 1 shows Indonesia's export of tobacco for the last seven years.

Production of tobacco in Indonesia that was fluctuated indicates this sector has not been organized well, considering that the harvested area has been increasing indeed. This fluctuation on quantity of both production and export would affect the comparative advantage of Indonesia's tobacco. It also would have effect on its competitiveness in the international market. In the long run, it could get the export quantity decreased and deflate the national foreign 
exchange if the government could not provide an appropriate solution. Furthermore, this condition would bring intrusion for producers and tobacco industries.

Table 1. Tobacco export Indonesia (Direktorat Jenderal Komoditas Perkebunan, 2014).

\begin{tabular}{ccc}
\hline Years & $\begin{array}{c}\text { Export } \\
\text { (tonnes) }\end{array}$ & $\begin{array}{c}\text { Percentage } \\
\text { Growth }\end{array}$ \\
\hline 2008 & 50.269 & 6.83 \\
2009 & 52.515 & 4.28 \\
2010 & 57.408 & 8.52 \\
2011 & 58.550 & 1.95 \\
2012 & 58.940 & 0.66 \\
2013 & 59.145 & 0.35 \\
2014 & 59.470 & 0.55 \\
\hline
\end{tabular}

The competition among producer countries entails them to enhance their product performance. Considering that condition, it is important to identify factors that would give significant impact on the competitiveness of Indonesia's tobacco in order to formulate the best policy for improving the competitiveness of Indonesia's tobacco in the international market.

\section{Research Methods}

\subsection{Method Of Location Determination}

This research was conducted in Indonesia in which the objects were the development of production and competitiveness of exported tobacco from Indonesia in the international market, with French and Thailand as comparator countries that have closest rank to Indonesia.

\subsection{Methods Of Data Collection}

The type of data in this study is secondary data in the form of time-based data (time series). Data is data associated with the value of exports, production, acreage of crops tobacco Indonesia, as well as related data comparison of two countries namely Thailand and France (the data value of the exports of each country) as a competitor because the two countries are the two countries on the rankings is closest to Indonesia in terms of export of tobacco based on data of the Food Agriculture Organization (FAO).

\subsection{Methods of Data analysis}

Quantitative data in this research was simply processed used Microsoft Excel 2010. Thus descriptive analysis employed to describe qualitative data based on credible sources. Analysis methods used are Revealed Comparative Advantage (RCA) and Export Competitiveness Index (ECI).

1. The Revealed Comparative Advantage (RCA)

RCA is ratio between export value of certain commodity from certain country with total export value from all producer countries. This indicator indicates the changes in comparative advantage or competitiveness of the country in the international market (Tambunan, 2003). According to Rifin (2003), the formula of $\mathrm{RCA}$ is:

$$
\mathrm{RCA}=\frac{\mathrm{X}_{\mathrm{i}} \mathrm{k} / \mathrm{X}_{\mathrm{i}}}{\mathrm{W}_{\mathrm{k}} / \mathrm{W}_{\mathrm{t}}}
$$

Description:

Xik : export value of Indonesia's tobacco at year $(\mathrm{t})$

$\mathrm{Xi}$ : export value of all commodities from Indonesia

Wk : export value of world's tobacco

$\mathrm{Wt}$ : export value of all commodities from all countries

RCA more than 1 indicates that Indonesia's tobacco has higher comparative advantage than other producer countries of tobacco in the world. Otherwise, it means that the comparative advantage of Indonesia's tobacco is poor, less than world's competitiveness.

\section{Export Competitiveness Index (ECI)}

ECI indicates the market share of certain commodity exported by certain country during a certain period (Hadianto, 2009). Amir (2000) in Saboiene (2009) uses this indicator to estimate the prospect of some industries in order to enhance national market growth in the international market. The formula of ECI is:

$$
\mathrm{ECI}=\frac{\left(\mathrm{Xk}_{\mathrm{i}} / \mathrm{X}_{\mathrm{w}}\right) \mathrm{t}}{\left(\mathrm{Xk}_{\mathrm{i}} / \mathrm{X}_{\mathrm{w}}\right) \mathrm{t}-1}
$$

Description:

Xki : export value of Indonesia's tobacco.

$\mathrm{Xw}$ : export value of world's tobacco.

$\mathrm{t}$ : on-going period

$\mathrm{t}-1$ : previous period

Value of ECI shows the trend of a producer country's competitiveness while compete with other producer countries. In other 
words, this index indicates whether Indonesia's tobacco is able to compete with other producer countries, considering their market share in the international tobacco market. If ECI is more than 1 , means that the trend of Indonesia's tobacco competitiveness tends to increase. Otherwise, its competitiveness is weakened.

\section{Results and Discussions}

1. The analysis Revealed Comparative Advantage (RCA)

Table 2. The result of analysis Revealed Comparative Advantage (FAO, 2015)

\begin{tabular}{cccc}
\hline \multirow{2}{*}{ Years } & \multicolumn{3}{c}{ RCA } \\
\cline { 2 - 4 } & Indonesia & France & Thailand \\
\hline 1991 & 5.84 & 0.63 & 7.50 \\
1992 & 8.10 & 0.62 & 9.27 \\
1993 & 7.04 & 0.85 & 8.78 \\
1994 & 4.53 & 0.96 & 6.94 \\
1995 & 5.07 & 1.11 & 3.74 \\
1996 & 5.57 & 1.00 & 4.78 \\
1997 & 6.23 & 0.98 & 4.96 \\
1998 & 10.68 & 1.23 & 5.95 \\
1999 & 6.56 & 1.39 & 3.68 \\
2000 & 5.81 & 1.26 & 4.27 \\
2001 & 8.47 & 1.12 & 3.97 \\
2002 & 5.57 & 1.46 & 4.48 \\
2003 & 4.20 & 1.67 & 3.94 \\
2004 & 4.48 & 3.42 & 3.82 \\
2005 & 4.63 & 3.20 & 4.58 \\
2006 & 3.54 & 3.96 & 3.46 \\
2007 & 1.42 & 0.87 & 1.51 \\
2008 & 0.92 & 0.92 & 1.16 \\
2009 & 1.11 & 0.75 & 0.94 \\
2010 & 1.07 & 0.82 & 0.81 \\
2011 & 0.54 & 0.68 & 0.48 \\
2012 & 1.36 & 1.11 & 0.38 \\
2013 & 1.38 & 0.88 & 0.43 \\
2014 & 1.56 & 0.58 & 0.44 \\
\hline
\end{tabular}

Based on RCA value from 2007 to 2014, indicated Indonesia's tobacco competitiveness tends to increase. In 2007, Indonesia's RCA for tobacco was 1,42 . In 2014 , it slightly increased to be 1,56, which was the highest value during that period. Thus, the lowest value was in 2011 at which the RCA was 0,54 since export value of Indonesia's tobacco in that year was the lowest one. Even though, the average growth of RCA was 2 percent per year.

According to Porter (1993), the fact that Indonesia has abundant natural resource and big number of human resource, brings an advantage for Indonesia to generate its competitiveness in the international market. But, the quality of its human resource which is relatively poor, gives a converse effect on Indonesia competitiveness. This abundant natural resource could not guarantee a stable productivity on Indonesia's tobacco, since the farmers are not capable enough to organize resource and maximize its potential productivity.

Other problems related to capital and infrastructure. Most of capital used in tobacco sector development was given by private sector. It made the national production intensely depends on foreign investment. On infrastructure sector, government has not provide a significant support for farmers in order to increase production and export of tobacco yet, especially on transportation and tariff issues.

Indonesia is an active producer country in the world trade of tobacco. During 1991 to 2006, RCA of Indonesia's tobacco had been more than1. But after 2006, the values showed a negative trend in which the RCA was decreasing year by year. Lately, by considering the results of RCA analysis for last seven years (2007-2014), RCA of Indonesia's tobacco tends to be stable and not too fluctuating. Generally, comparative advantage of Indonesia's tobacco from 1991 to 2014 was in a good state, since the RCA value was 5,25 in average.

These results were in line with Daryanto's research which also indicated that Indonesia's tobacco has a comparative advantage in the international market. Moreover, Safitri (2011) stated that during 2000 to 2009 , Indonesia's export of tobacco was in the maturity phase to increase its competitiveness and market concentration in the international market.

2. Analysis of Export Competitiveness Index (ECI)

Analysis of ECI is used to identify if comparative advantage of tobacco has positive trend in the international market. This trend could inform the competitiveness of Indonesia's tobacco and which country would be the competitors. Results of ECI show that competitiveness of Indonesia's tobacco was relatively better than French and Thailand during 2007 to 2014. 


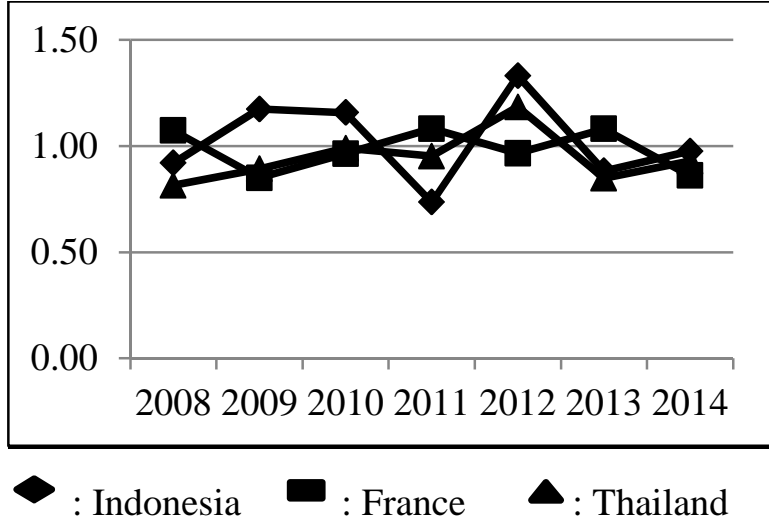

Figure. The trend of the competitiveness of Indonesia, France and Thailand (FAO, 2000).

The lowest value of Indonesia's ECI $(0,78)$ came about year 2011 at which its performance was worse than France and Thailand. Negative growth also occurred in 2013, it was caused by decreasing on productivity of tobacco. But generally, Indonesia's tobacco has higher competitiveness than its competitors, in which France and Thailand were set as comparator countries.

\section{Conclusions}

Indonesia's tobacco has higher comparative advantage than France and Thailand due to their RCA values, at which Indonesia's RCAs, during 1999-2014, are the highest in average.

The competitiveness of Indonesia's tobacco tends to increase (has a positive trend) by considering its ECI values. This result also indicates that exporting performance of Indonesia's tobacco is better than both of France and Thailand.

\section{References}

[1] Amir, M.S. 2000. Seluk Beluk dan Teknik Perdagangan Luar Negeri. PPM. Jakarta.

[2] Baroh, I. 2014. Daya Saing Kopi di Indonesia di Pasar Domestik dan Pasar Internasional. Disertasi.

[3] Firmansyah. 2014. Pedoman Standarisasi Mutu Tembakau,. www.disbun. jabarprov. go.id.

[4] Daryanto, A. 2010. Posisi Daya Saing Pertanian Indonesia Dan Upaya Peningkatannya. Fakultas Ekonomi dan Manajemen-Institut Pertanian Bogor.
[5] Direktorat Jenderal Tanaman Perkebunan, 2014. Mengenal Varietas Unggul Tembakau di Jawa Timur Sebagai Upaya Meningkatkan Mutu Benih. PBT Ahli Muda BBPPTP. Surabaya.

[6] Food And Agricultural Organization (FAO). 2015. Produksi Tembakau Dunia. Diakses pada 20 April 2015.

[7] Food And Agricultural Organization (FAO). 2015. Nilai Ekspor dan Impor Tembakau Dunia. Diakses pada 20 April 2015.

[8] Hadianto. 2009. Perangkat dan Model Analisis. Investasi di Pasar Internasional. Jakarta: Gramedia.

[9] Porter, M. E. 1993. Keunggulan Bersaing Menciptakan dan Mempertahankan. Erlangga, Jakarta.

[10] Rifin, A. 2013. Competitiveness of Indonesia's Cocoa Beans Export in the World Market. International Journal of Trade, Economics and Finance, Vol. 4, No. 5, October 2013.

[11] Saboniene, A. 2009. Lithuanian Export Competitiveness: Comparison with other Baltic States. Vol 62, No 2.

[12] Safitri, L. 2011. Analisis Kinerja Ekspor Dan Impor Tembakau Indonesia Periode 2000-2009. Fakultas Ekonomi Universitas Trisakti. Jakarta.

[13] Tambunan, T. 1999. Perekonomian Indonesia. Jakarta.

[14] Tambunan, T. 2001. Industrialisasi di Negara sedang Berkembang: kasus Indonesia. Ghalia Indonesia, Jakarta. 